\title{
Proposal of a Modelling of the Innovation Process in an International Manufacturing Company
}

\author{
Pauline Lacom ${ }^{1,2^{*}}$, Florence Bazzaro ${ }^{1}$, Jean-Claude Sagot ${ }^{1}$
}

\begin{abstract}
Nowadays, to cope with the competition, and to ensure the durability of their activities, companies have to be able to innovate. Manufacturing companies operating in a B2B market often perceive innovation as a technological result. However, innovation is often more characterized as a process. The needs of the users, and not only the technology, can achieve innovation. In this context, our paper intends to determine how to involve better the users in the innovation process of an international manufacturing company, which is, according to us, representative of the current manufacturing companies. The aim of our research paper is to help manufacturing companies to manage innovation led by users, and to implement their innovation process so that they will be able to set up specific tools for each action of the process. The study proposes a diagrambased language Structured Analysis and Design Technique (SADT) that is based on the normative guide FD X50-271 of the French national organization for standardization (AFNOR). The SADT model we propose usefully complements this guide, to make the innovation process more understandable, practical and operational, for manufacturing companies, which are often helpless when faced with the subject. A critical analysis of the model we propose completed in a manufacturing company through semi-structured interviews of the innovation team and questionnaire for all the employees shows the application of the model in the company.
\end{abstract}

Keywords: innovation process; manufacturing company; SADT; innovation process model; B2B market.

Submitted: March 29 2017 / Approved: Jun 30 2017

\section{Introduction}

To cope with increasing competition and to make their activities sustainable, manufacturing companies, where competition is hard, and demand never stops evolving, have to innovate (Andrade et al., 2015). According to Freeman (1991), innovation can be defined as "an iterative process initiated by the perception of a new market and/or new service opportunity for a technology-based invention which leads to development, production, and marketing tasks striving for the commercial success of the invention." Companies know the importance to be innovative, and to diversify their innovation capabilities, but they might learn how to set it up (Camargo et al., 2015). Researchers have tried to simplify the concept of innovation by proposing classifications of it, especially to show that innovation is not only a technical novelty (Garcia and Calantone, 2002). This study focuses on innovation driven by users. It involves people who use the product in their work or home life, who may innovate for their utility, to obtain a solution to their needs and expectations (Von Hippel, 2005). The users may include different groups of people using a product, during its life cycle such as the inventor, the client, the designer, the quality manager, etc. Innovation driven by users is already well implemented in companies operating in a B2C market (i.e. companies sell their products to private individuals), like health equipment (Lüthje, 2004). Manufacturing companies operating in a B2B market, which only sell their products to professionals, often restrict innovation to the Research \& Development department; thus the users are few considered. However, several collaboration kinds have to be set up between the different services of a company to favor innovation (Becker and Dietz, 2004). Our study hypothesizes that innovation driven by users can be applicable for manufacturing companies operating in a B2B market, to develop new types of innovation, and to be more competitive.

As far as we know, few research works have focused on the implementation of innovation driven by users in such companies. This study aims to help the companies with $\mathrm{B} 2 \mathrm{~B}$ marketing system to manage innovation driven by users and to implement an innovation process, especially by setting up specific tools. This paper firstly presents the innovation process, and particularly the one based on the normative guide FD X50-271 of the AFNOR (2014). Then, the Structured Analysis and Design Technique (SADT) language (Ross, 1977) models the innovation process. As an actor of a partner manufacturing company, which stays representative of the current manufacturing companies, the developed model is analyzed critically through a comparative stu$\mathrm{dy}$ of the theory and the practice (with semi-structured interviews of the innovation team and questionnaire for all the employees of the company).

\section{The innovation process: theoretical study}

The evolution of the vision and of the management of innovation in a company implies the evolution of the definition of innovation itself. Contrary to the traditional view of innovation, such as the commercialization of an invention (Schumpeter, 1942), it is more and more defined as being a process that brings something new to a company or a market. By defining innovation as a process, it enables the companies to depict, manage it and measure it (Zhang et al., 2013). Several kinds of innovation processes are existing: the linear model of Chanaron (1992), whereby the innovation process is sequential and

(1) Pôle de recherche ERCOS, laboratoire ELLIADD (E.A. 4661) - Université de Bourgogne Franche-Comté -UTBM, 90010 Belfort Cedex, France. (2) LISI AUTOMOTIVE SA, 2 rue Juvénal Viellard, 90600 Grandvillars -France.

${ }^{\star}$ Corresponding author: pauline.lacom@utbm.fr 
mainly product and tech oriented; the " whirling " model of Akrich (1988), which presents a process exposed to many iterations and multidisciplinary actors; and the chain-linked model of Kline and Rosenberg (1986), which is composed of five major pathways, including the central chain-of-innovation, and a box which explains the links between the company and technical know-how. These models seem to be compatible and complementary. However, they mainly detail the methodological approach of the innovation process, but the required resources to set up the process are less detailed. As being an actor of a partner manufacturing company, we need to federate the resources, especially by applying the innovation process of the standard guide FD X50-271 of the AFNOR (2014) (ISO standard on innovation management is currently at the proposal stage). As shown in Figure 1, and according to the AFNOR standard, the innovation process is divided into four domains (marketing and sales; technology; legal, normative and financial; management and organization), and in four steps (exploration; assessment and decision; management of projects; capitalization). The interaction between these domains and steps enables to determine the actions of the process. For each of these actions, it is possible to define the methodological, human, material and technological resources that are required to achieve them. This view of the innovation process emphasizes the definition of each action, and the interactions between the resources, especially the human ones. In the case of innovation driven by users, the latter are actors of the different steps of the process, and the notion of interactions between them is very significant. The user has to be involved in the domains marketing and sales (to determine their expectations and needs), and technology (to be sure that the solution found answers their needs). The user has to be involved in the steps exploration and capitalization. Then, the user has to contribute to the actions A1 "Look for innovation opportunities" and D2 "Capitalize on technologies." We partly based this study on this view of the innovation process, and it is focused on the action A1, to involve the users as soon as the first step. The AFNOR standard does not detail the accurate content and the specific resources of each action. Therefore, we will go into this action A1 and its resources in depth.

Figure 1. The innovation process according to the AFNOR (2014)

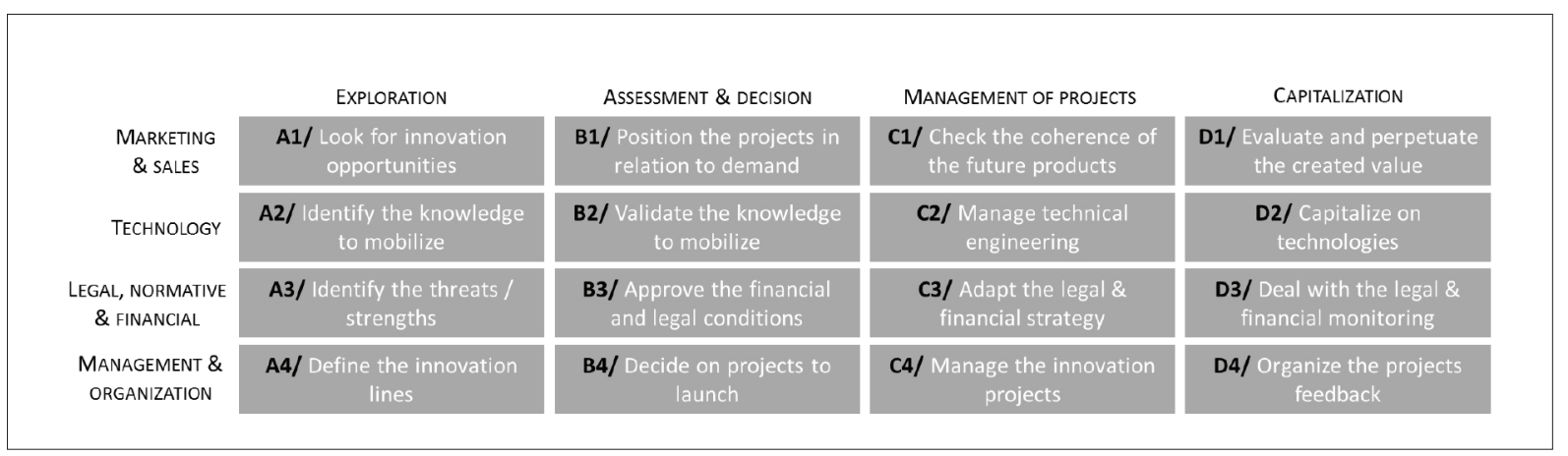

\section{Proposed model: the innovation process as an SADT}

In order to detail the action A1 "Look for innovation opportunities" of the AFNOR, after a review of modelling methods and languages that are used to model business processes (SADT, EPC, BPMN, etc.), we have chosen the use of SADT (Structured Analysis and Design Technique) (Ross, 1977). This classic tool has often been used in manufacturing companies, because it is easily accepted, thus justifying our choice (Colquhoun et al., 1993). This paper explains all the subactions of the action A1 using SADT, with the related resources.

\section{The diagram based language SADT}

SADT represents a process in a microscopic way, by detailing its different actions as a hierarchy of functions. An SADT decomposes the actions with the top-down approach, which illustrates the process at several levels and provide a better understanding of this process to the different levels of the hierarchy of a company: this is especially interesting and specific to SADT. Furthermore, the ICOM formalism (Ross, 1985) characterizes SADT, including input data (I); control data $(\mathrm{C})$; output data $(\mathrm{O})$; mechanism $(\mathrm{M})$, which highlight the actions, their order, their tools and their resources. We have decided to focus on human resources, and specifically on the actors, and their roles and skills, who realize the action.

\section{The innovation process as an SADT}

The representation as an SADT of the innovation process analyzes what is lacking for a company, its mistakes, and the inconstancy of its actual system (regarding involvement of actors for example). The SADT model developed in this study identifies the different sub-actions of a manufacturing company, which has to perform to achieve the action A1 of the AFNOR, by involving the users. We have created it thanks to a study of the existing literature, especially in the innovation process, the management of innovation, and the features of innovation for a manufacturing company. The action A0 "Look for innovation opportunities with the participation of the users" of the first level of our SADT is the action coming from the standard guide of the AFNOR, with an emphasis on the users (Figure 2). Users are the most important element in the process, who are requested several times, from the research department (M2) to the suppliers (M11), including the marketing (M3), the quality (M10), the clients (M12), etc. 
Figure 2. Action A0 of our SADT model

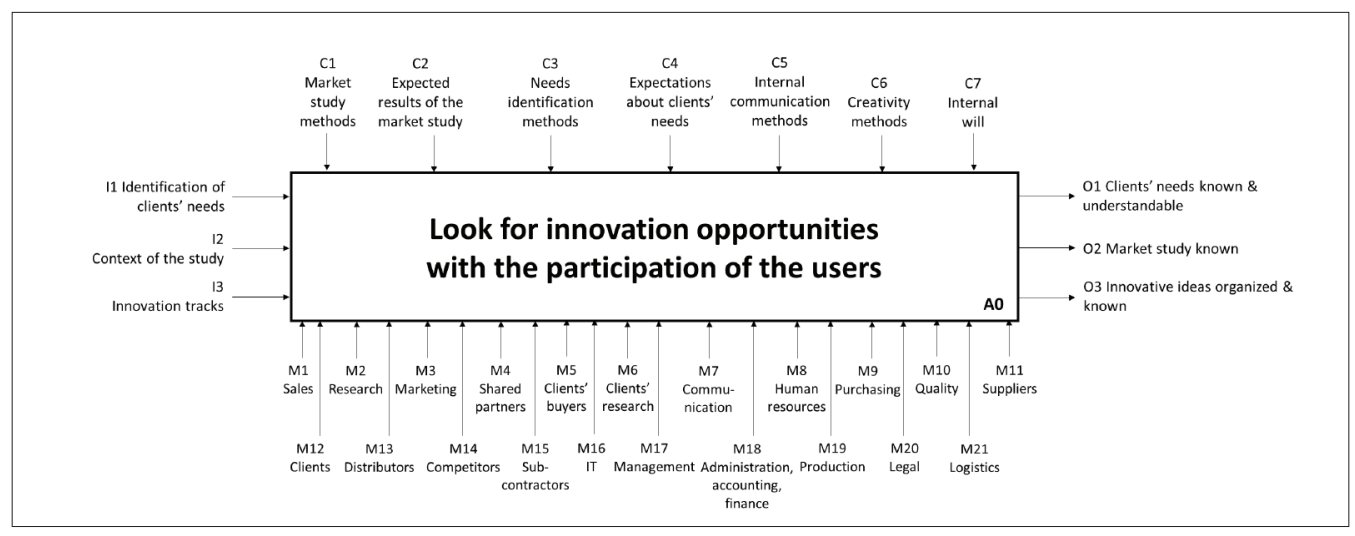

The second level of our SADT depicts the three sub-actions of our action A0. These three sub-actions are A1 "Determine the users' needs," A2 "Analyze the market," and A3 "Find innovating ideas." They enable to understand better the action A0, but they stay generic. We propose to detail them in the third level of our SADT. Figure 3 details the action A1 "Determine the users' needs". It consists in determining the implicit and explicit needs of the users (Kano et al., 1984). It is divided into three sub-actions: (i) Identify expressed users' needs: it is about identifying the users' needs (input data: I), such as "I need your parts to be delivered in smaller quantities." The salesmen and research department (human resources: M) can achieve this action, and rephrase the needs in an internal language, so that everybody can understand them (output data: O); (ii) Identify non-expressed users' needs: it is about identifying the users' needs (I) which are not expressed, such as "I would like to produce green cars", and not only to propose lighter cars. The marketing department (M) can do a monitoring of these needs $(\mathrm{O})$. The salesmen and the research department (M) can detect the non-expressed needs of the users. External actors (M) can have information on the users not known by the company; (iii) Share the users' needs (internally): it is about sharing the users' needs (understandable) (I), so that they are known and understood by all the departments of the company $(\mathrm{O})$. The internal communication department of the company, or sometimes the human resources department $(\mathrm{M})$, can share this information.

Figure 3. Details of the action A1 "Determine the users' needs" of our SADT, with the ICOM formalism

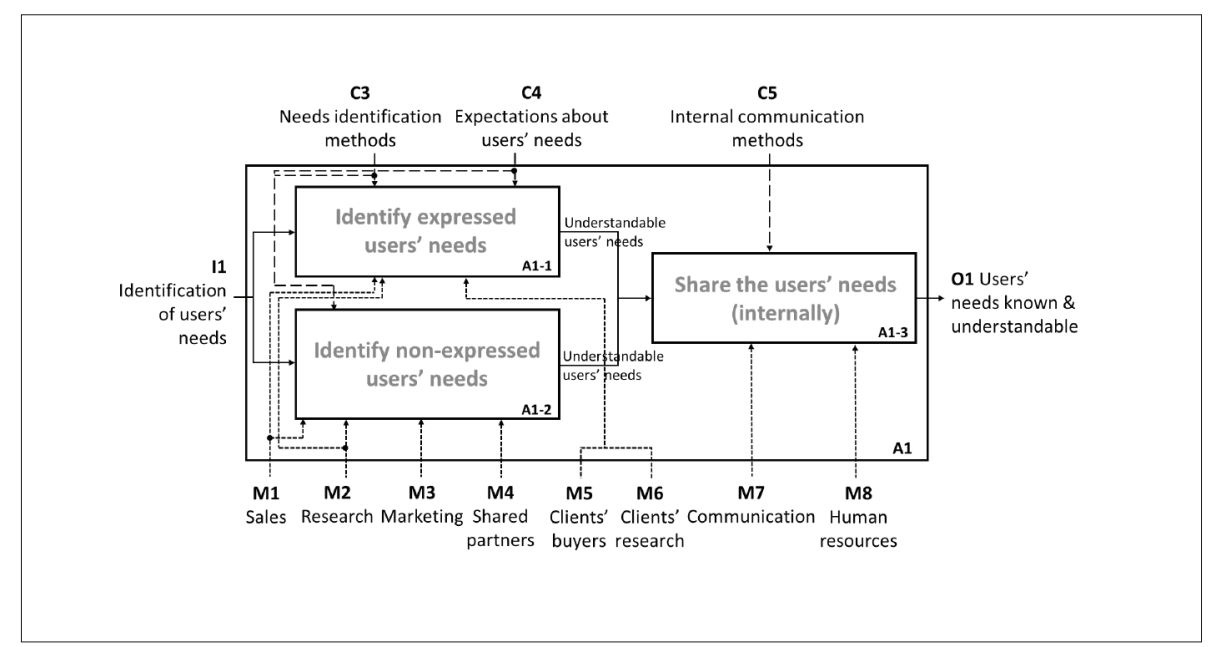

The action A2 "Analyze the market" consists of making a comprehensive market study in which the company is operating (Pickton and Broderick, 2005). The action is again divided into three sub-actions: (i) Analyze the macro-environment of the company: it consists of studying the context (I), to determine its influence on the innovation process, and have a complete macro-environment analysis $(\mathrm{O})$. For example, they can especially study the legislation on green cars. The marketing department (M) can do it, but other departments can also assist it; (ii) Analyze the micro-environment of the company: it consists of studying the context (I), to determine its influence and have a complete micro-environment analysis $(\mathrm{O})$. All the actors who have information about the context can do this analysis (M) (e.g. salesmen have information about the clients, distributors, and competitors, etc.); (iii) Share the information (internally): it is about sharing the analyses of the market (I), so that all the departments of the company know them (O). The internal communication department of the company, or sometimes the human resources department (M), can share this information. 
After having achieved all the monitoring and analysis actions, the company can embark upon the search of ideas (Fink et al., 2012): it is the aim of the action A3 "Find innovative ideas." This action is again divided into two sub-actions: (i) Stimulate the creativity of the different actors: it consists in stimulating the creativity of all of them who are involved in the innovation process, to transform their innovation tracks (I) into concrete innovative ideas (even in a jumble) $(\mathrm{O})$. For example, an employee can know that a process can be improved, without knowing how to do it; creativity methods could help him to find how to improve the process. All the departments of a company (M) can do this action. Some external actors could also be involved if they want to. For example, the suppliers can propose their innovative ideas, which could lead to new raw materials; (ii) Share the innovative ideas (internally): it is about sharing the innovative ideas that have been selected in the company (I), so that all the departments know them $(\mathrm{O})$. The internal communication department of the company, or sometimes the human resources department (M), can share this information.

The model proposed in this study simplifies the management of the innovation process of a company, as each actor knows what it has to do and at what time it has to do it. The SADT model could usefully complete the process proposed by the standard of the ANOR, especially by detailing the first exploratory state. Thus, as part of our research works, we wanted to apply the innovation process of the AFNOR, and more precisely its action A1 "Look for innovation opportunities" to an international manufacturing company operating in a B2B market, which is especially solicitous over the innovation led by its users.

\section{Methods}

The chosen company is a French automobile subcontractor, existing for more than two centuries, and with more than 3,200 employees in about twenty plants in the world. Today, it is important to remember that it is complicated for companies to preserve or to protect what is essential to their development, that is to say: their technic creations, their know-how and more widely their strategic information. We think that the chosen company remains indicative, even representative of the current manufacturing companies, given its size, its history, and its international vision. The company would like to involve more its users in its innovation process. Its aim is to be differentiated from its competitors, and to be perceived as a company that can be a creative force, and not only a supplier of parts. The first part of our study was composed of individual semi-structured interviews (Berthier, 2016) of about 45 minutes, with each member of the innovation team of the company. The multidisciplinary innovation team brings together ten members: three from the sales department, five from the research department, and two people from the marketing department. People of the sales and the research departments are in charge of different product ranges, thus enabling a broad representation of the business sectors of the company in the innovation team. The second part of our experimentation was composed of a short questionnaire (Salazar and Holbrook, 2004) of 10 minutes. We e-mailed it to around 1,800 employees. Its main aim was to determine the involvement of the users in the innovation process. To figure out this point, we focus on different points: the departments that are responsible for innovation, the involvement of the employees in the innovation process, the capacity to detect the clients' needs, etc. (Von Hippel, 2005). We conducted a pre-test with ten employees of the company to check question comprehension and to sample the types of answers to get. 245 (13.6 \%) employees filled in anonymously our questionnaire. All the departments of the company are represented, as well as the social status. We used Chi-Square Test of independence or Chi-Square Goodness-of-Fit Test in our statistical analyzes, and we accepted $\mathrm{p}<0.05$ as statistically significant.

\section{Results}

Firstly, through our questionnaire, we have asked the employees to mark their involvement in the research of innovation in the company on a scale of 1 to 5 ( 5 is the best mark) (Figure 4). Our results show a significant difference in the involvement of the employees in the research of innovation depending on the departments of the company ( $R \& D$ versus other departments) $\left(\mathrm{X}^{2}(4)=10.81 ; \mathrm{p}<0.05\right)$; people from the R\&D department are more involved than the others. $72 \%$ of the employees of the R\&D department gave a mark of 3 or more to their involvement in the research of innovation, whereas only $56 \%$ of the other employees gave a mark higher than or equal to 3 .

Figure 4. Mark given by the employees on their involvement in the research of innovation ( 5 is the best mark)

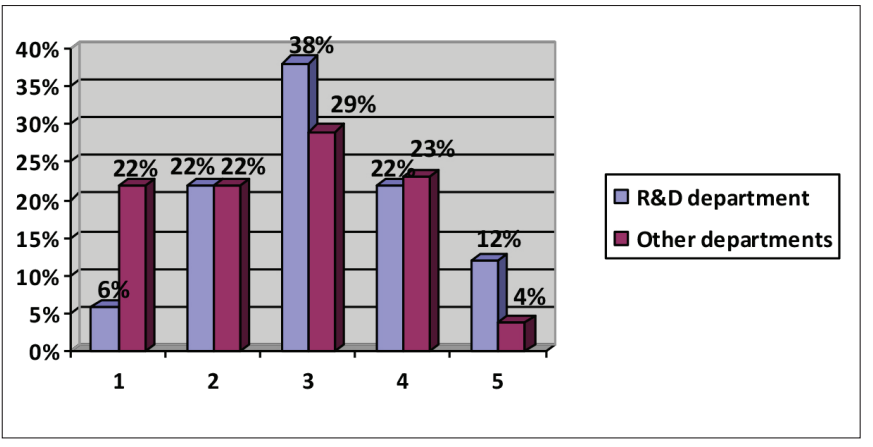

Then, we have applied our action A1 “Determine the users' needs" to the studied company. The company tends to focus on the expressed needs of its users. To determine its users' needs, the company limits itself to the information it has internally, or the information easy to find alone, without appealing to partners who are shared with the users (e. g. the suppliers), who can have other information. Indeed, according to all the members from the sales and marketing departments of the innovation team, the needs are only known when the users express them, and the information is only shared with the technical teams. Through our questionnaire, we have also asked the employees to mark the capacity of the company to detect its clients' needs on a scale of 1 to 5 (5 is the best mark) (Figure 5). The results of our Chi-Square Goodness-of-Fit Test show a significant difference in the capacity of the company to detect its clients' needs in comparison with a set of observations $\left(X^{2}(4)=125.92\right.$; $\mathrm{p}<0.001) .36 \%$ of the employees gave a mark lower than 3 , whereas only $21 \%$ of the employees gave a mark higher than 3 . 
Figure 5. Mark given by the employees in the capacity of the company to detect its clients' needs (5 is the best mark)

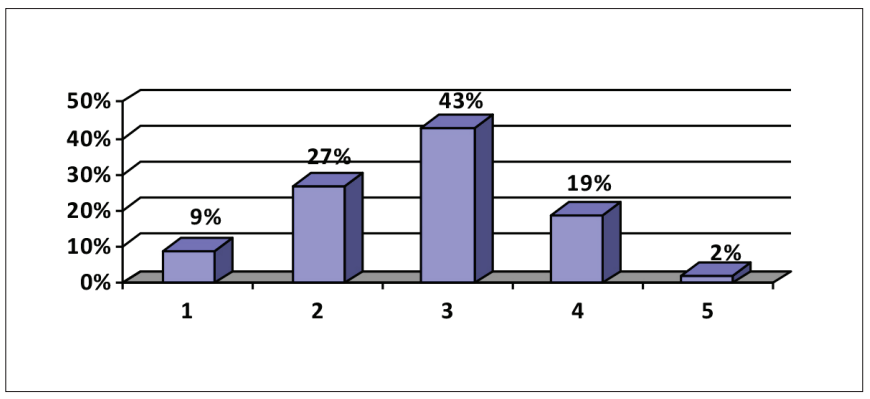

Afterward, we have applied our action A2 "Analyze the market" to the studied company. The company has well understood the importance of the competition analysis. Indeed, through our semi-structured interviews, we asked the members of the marketing department of the innovation team if a competitor analysis was organized, at which frequency, with which information, etc. They organize a competitor analysis every year, with mainly their key figures. We also asked them if other actors of the market were analyzed. They analyze some clients when the general management or the sales department ask for it. Then, according to the members of the sales and the marketing departments, the information is in general only shared between them, with the general management and the research department

Then, we have applied our action A3 "Find innovative ideas" to the studied company. The company has difficulties finding innovative ideas. Apart from some proposals of technic improvements, the company cannot propose innovative ideas. In our questionnaire, we have asked the employees if they have already participated in meetings dedicated to innovation. Our results show a highly significant difference ) $\left(\mathrm{X}^{2}(1)=11.11 ; \mathrm{p}<0.001\right)$ in the participation of the employees in innovation meetings depending on their departments ( $R \& D$ versus other departments; people from the R\&D department are more involved than the others. $40 \%$ of the employees of the R\&D department have already participated in meetings dedicated to innovation, whereas only $18 \%$ of the other employees have done it. We have also asked the employees if they had ever heard about tools/means to transmit their innovation ideas: more than $80 \%$ of the employees have never heard about that.

\section{Discussion}

The necessity to innovate in companies has been amply demonstrated now. It is even truer for manufacturing companies that have to cope with high competition. Companies face a lot of innovation types (Garcia and Calantone, 2002). Even though companies have understood the importance of innovation, they have to choose which innovation they want to set up, and how to set it up (Camargo et al., 2015). In this paper, we focused on the innovation led by users. This type of innovation is already well implemented in companies operating in a $\mathrm{B} 2 \mathrm{C}$ market, but not as well in companies operating in a B2B market (Lüthje, 2004). To help these companies, authors have proposed several innovation processes. We have chosen to focus on the one proposed by the AFNOR in its standard guide FD X50-271, as it details the methodological approach of the process, but also the corresponding resources. To help manufacturing companies to set up the theoretical innovation process of the AFNOR, we have proposed in this paper a view of this process that uses a diagram-based language SADT. Thanks to this approach, we think that all the actors of manufacturing companies could better understand the actions they have to achieve to develop their innovation process. Our approach enables to easily detect the lacks, the mistakes, etc. of this process, to better structure and manage it. We have done a case study in a manufacturing company, through semi-structured interviews conducted with a multidisciplinary team in charge of innovation, and through a questionnaire intended for all the employees, to validate its relevance.

Firstly, our results show that the R\&D department of the studied company is more involved in the innovation process than the other departments. This result is in agreement with the ones of the literature, which show that the R\&D has always had an essential role in manufacturing companies. After having studied the main American manufacturing companies between 1976 and 1985, Morbey (1988) concludes that there is a strong link between the expenses in R\&D and the growth of sales. This is why, since this period and even now, the R\&D, according to Rothwell (1992) often stays the main source of innovation. However, it is also important to emphasize that the R\&D is not as important for all manufacturing companies. After having studied 130 American companies, Freeman has concluded that the bigger the company is, the more important the R\&D is. According to him, the R\&D generates twice the income for companies with more than 25,000 employees than for the ones with less than 25,000 employees (Freeman and Soete, 1997). The study of Italian manufacturing companies proposed by Santarelli curbs the proposition of Freeman, by assuring that the R\&D is very efficient for companies of more than 500 employees, as well as the involvement of external actors of the company (Santarelli and Sterlacchini, 1990). Thus, few actions of the AFNOR standard are integrated and respected in these companies. Indeed, because of the high involvement of the R\&D department, the company focuses on the technology domain, which only represents four actions of the AFNOR standard.

Then, our results show that the company tends to focus on the expressed needs of its users. It is strengthened by the works of Bailom et al. (2007), who have studied the failure of different companies, and have come to the conclusion that companies focus on expressed and communicated needs of their clients, particularly in the needs publicly published in the market studied. Thanks to the analysis of twenty-six American Fortune 500 financial services firms, Alam (2006) has observed that the problem of needs identification is not only linked to the companies, but also to the clients. Indeed, some of them can impose a short-term vision, or not fully commit themselves because of the lack of any tangible benefit to them. The SADT in the following Figure 6 presents the details of these observations. We built it in partnership with the innovation team of the company. We can highlight some differences between the theoretical model and the reality of the company. For example, the human resources $(\mathrm{M})$ are different: the company does not involve the shared partners and the client's research department, and there is no internal communication department. 
Figure 6. Application of the action A1 "Determine the users' needs" of our SADT to the studied company; the company does not apply the crossed items

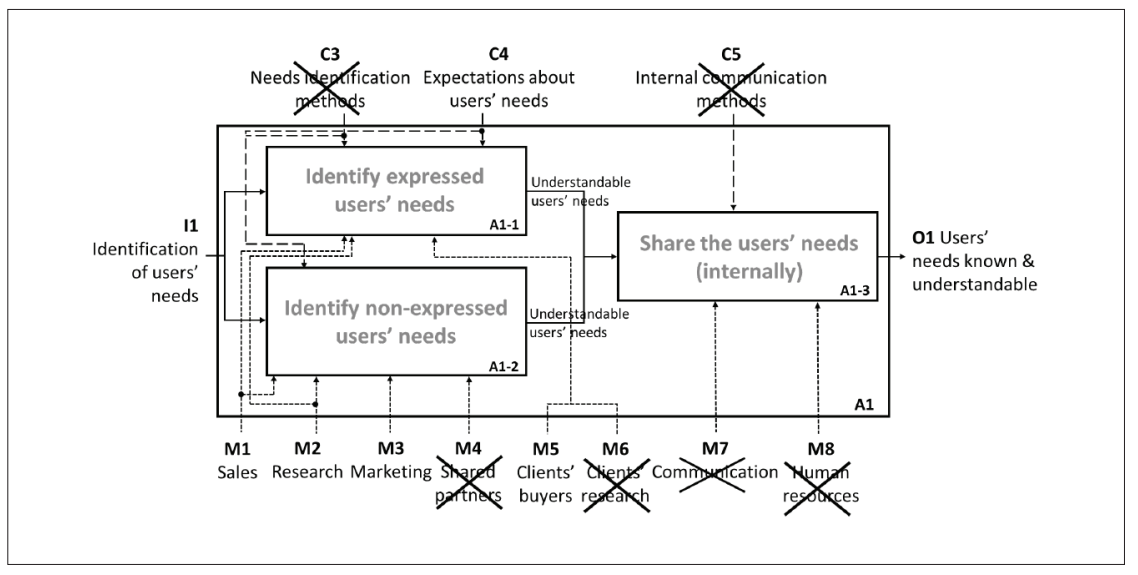

Afterward, our results show that the company mainly focuses on the analysis of its competitors, and not on the other actors of its environment. It is probably linked to the fact that the automobile industry has been a highly competitive market for a long time. Indeed, Pavlínek and Janák (2007) have shown that competition highly influences the network and the market in the automotive industry, and suppliers are mainly selected on a price-based competition. Consequently, the company limits itself to the common services to analyze the market: the marketing, sales and research departments. Besides, the information circulates with difficulty from one department to another one. Here again, we can highlight some differences between the theoretical model and the reality of the company. For example, the human resources (M) are different: the company does not involve the majority of the external actors who could be involved in the action, the suppliers and the clients are very little involved, and the company only involves the marketing, the sales, the research and the purchasing departments. There is also no internal communication department in the company.

Finally, our results show that the company has difficulty finding ideas that are not technical, mainly because technic departments are the ones the most involved in creativity meetings. According to Vissers and Dankbaar (2002), who have interviewed NPD (new product development) supervisors of medium-sized companies, manufacturing companies consider innovation and creativity as teamwork. However, they involve the "R\&D team" in the creativity step, but it is limited to few departments of the company: the engineering, the manufacturing, and the marketing. Here again, we can highlight some differences between the theoretical model and the reality of the company. For example, the human resources $(\mathrm{M})$ completely differ: the company only involves technic teams of the research department, and there is no internal communication department.

By putting to the test our SADT model in a manufacturing company, we were able to highlight the lacks and the mistakes linked to innovation in the company. They can easily identify the points where they can get better. The following Table 1 proposes a summary of the improvement lines of the first action of our SADT. It is possible to do the same thing for the other actions of our SADT.
Table 1. Recommendations for the studied company for the first action of our SADT

\begin{tabular}{l}
\hline $\begin{array}{l}\text { Actions of the SADT } \\
\begin{array}{l}\text { Al "Determine the } \\
\text { users' needs" }\end{array} \\
\text { - }\end{array} \begin{array}{l}\text { Better identify its users' needs, expressed or } \\
\text { non-expressed; }\end{array}$ \\
- $\begin{array}{l}\text { Diversify internal and external actors } \\
\text { involved; }\end{array}$ \\
$\begin{array}{l}\text { Prioritize its users' needs before thinking } \\
\text { about its technical skills; }\end{array}$ \\
- Better share the information internally.
\end{tabular}

The company concurs with the model we propose and considers that our approach is instructive and pertinent. Indeed, further to the recommendations we have done after having applied the SADT to the studied company, the company has decided to set up several tools and methods to favor the implementation of its innovation process. For example, to involve more of its collaborators, and diversify the skills of the people involved (action A3 "Find innovative ideas"), the company will set up an innovation room, and organize innovation contests. To help the company, we work on the identification of tools that should favor the implementation of the innovation process. It may differ from one company to another one, according to its features (size, market, etc.) and its culture (Katsikis et al., 2016). This is why we work on a proposition of a tools selection method to support and favor innovation led by users in a manufacturing company, according to these factors.

\section{References}

AFNOR, 2014. FD X50-271: Management de l'innovation - Guide de mise en oeuvre d'une démarche de management de l'innovation (Norme).

Akrich, M., Callon, M., Latour, B., 1988. A quoi tient le succès des innovations? 1 : Lart de l'intéressement; $2:$ Le choix des porte-parole. Gérer Compr. Ann. Mines 4-17 \& 14-29. 
Alam, I., 2006. Removing the fuzziness from the fuzzy front-end of service innovations through customer interactions. Ind. Mark. Manag. 35, 468-480. doi:10.1016/j.indmarman.2005.04.004

Andrade, L.P.C. da S., Will, M., Mascarenhas, L.A.B., Silva, R.C. da, Gomes, J. de O., 2015. Evaluation of Technological Trends and Demands of the Manufacturing Industry to a Center of R\&D\&I. J. Technol. Manag. Innov. 10, 104-119.

Bailom, F., Matzler, K., Tschemernjak, D., 2007. Enduring Success: What Top Companies do Differently. Springer.

Becker, W., Dietz, J., 2004. R\&D cooperation and innovation activities of firms-evidence for the German manufacturing industry. Res. Policy 33, 209-223. doi:10.1016/j.respol.2003.07.003

Berthier, N., 2016. Les techniques d'enquête en sciences sociales: méthodes et exercices corrigés. A. Colin, Paris.

Camargo, M., Boly, V., Morel, L., 2015. Mesurer l'innovation en entreprise : un levier essentiel pour la réussite des projets innovants. Presses universitaires de Nancy : Éditions universitaires de Lorraine, Nancy.

Chanaron, J.J., 1992. Technology, Strategy and Management. Creat. Innov. Manag. 1, 142-150. doi:10.1111/j.1467-8691.1992.tb00045.x

Colquhoun, G.J., Baines, R.W., Crossley, R., 1993. A state of the art review of IDEFO. Int. J. Comput. Integr. Manuf. 6, 252-264. doi:10.1080/09511929308944576

Fink, A., Koschutnig, K., Benedek, M., Reishofer, G., Ischebeck, A., Weiss, E.M., Ebner, F., 2012. Stimulating creativity via the exposure to other people's ideas. Hum. Brain Mapp. 33, 2603-2610. doi:10.1002/hbm.21387

Freeman, C., 1991. The nature of innovation and the evolution of the productive system, in: Technology and Productivity: The Challenge for Economic Policy. OECD, Paris, pp. 303-314.

Freeman, C., Soete, L., 1997. The Economics of Industrial Innovation. MIT Press.

Garcia, R., Calantone, R., 2002. A critical look at technological innovation typology and innovativeness terminology: a literature review. J. Prod. Innov. Manag. 19, 110-132. doi:10.1016/S0737-6782(01)00132-1

Kano, N., Seraku, N., Takahashi, F., Tsuji, S., 1984. Attractive Quality and Must-Be Quality. J. Jpn. Soc. Qual. Control 14, 147-156.

Katsikis, N., Lang, A., Debreczeny, C., 2016. Evaluation of Open Innovation in B2B from a Company Culture Perspective. J. Technol. Manag. Innov. 11, 94-100.
Kline, S.J., Rosenberg, N., 1986. An overview of innovation, in: The Positive Sum Strategy: Harnessing Technology for Economic Growth. National Academies Press, pp. 275-305.

Lüthje, C., 2004. Characteristics of innovating users in a consumer goods field: An empirical study of sport-related product consumers. Technovation 24, 683-695. doi:10.1016/S0166-4972(02)00150-5

Morbey, G.K., 1988. R\&D: Its relationship to company performance. J. Prod. Innov. Manag. 5, 191-200. doi:10.1016/0737-6782(88)90022-7

Pavlínek, P., Janák, L., 2007. Regional Restructuring of the Škoda Auto Supplier Network in the Czech Republic. Eur. Urban Reg. Stud. 14, 133-155. doi:10.1177/0969776407076101

Pickton, D., Broderick, A., 2005. Integrated marketing communications, 2nd ed. Prentice Hall/Financial Times, Harlow.

Ross, D.T., 1985. Applications and Extensions of SADT. Computer 18, 25-34. doi:10.1109/MC.1985.1662862

Ross, D.T., 1977. Structured Analysis (SA): A Language for Communicating Ideas. IEEE Trans. Softw. Eng. SE-3, 16-34. doi:10.1109/ TSE.1977.229900

Rothwell, R., 1992. Successful industrial innovation: critical factors for the 1990s. RD Manag. 22, 221-240. doi:10.1111/j.1467-9310.1992.tb00812.x

Salazar, M., Holbrook, A., 2004. A debate on innovation surveys. Sci. Public Policy 31, 254-266.

Santarelli, E., Sterlacchini, A., 1990. Innovation, formal vs. informal $\mathrm{R} \& \mathrm{D}$, and firm size: Some evidence from Italian manufacturing firms. Small Bus. Econ. 2, 223-228. doi:10.1007/BF00389530

Schumpeter, J.A., 1942. Capitalism, Socialism and Democracy, 1st ed. Routledge, New York.

Vissers, G., Dankbaar, B., 2002. Creativity in Multidisciplinary New Product Development Teams. Creat. Innov. Manag. 11, 31-42. doi:10.1111/1467-8691.00234

Von Hippel, E., 2005. Democratizing innovation: The evolving phenomenon of user innovation. J. Für Betriebswirtschaft 55, 63-78. doi:10.1007/s11301-004-0002-8

Zhang, L., Seidel, R., Shahbazpour, M., Haemmerle, E., (2013). A three-dimensional innovation process capability assessment tool. Presented at the 2013 6th International Conference on Information Management, Innovation Management and Industrial Engineering, pp. 151-155. doi:10.1109/ICIII.2013.6703537 
